\title{
The Effect of Price, Promotion and Location on Purchasing Distro Sport Purchases (Study on Agung Jaya Cikarang Distro Sport Consumer)
}

\author{
Nur Aeni \\ Pelita Bangsa University, Indonesia \\ \{nur.aeni@pelitabangsa.ac.id\}
}

\begin{abstract}
This study aims to determine the effect, price, promotion and location on purchasing decisions at Distro Sport. This research was conducted on Distro Sport consumers with a total sample of 60 respondents, the sample technique used was nonprobability sampling technique and the sampling method using Purposive Sampling. This type of research is quantitative explanatory and uses descriptive data analysis techniques, multiple linear regression test, classic assumption test and hypothesis testing using SPSS 22 for Windows evaluation Version software. The results of this study indicate that the price variable has a positive and significant effect on purchasing decisions, promotion variables have a positive and significant effect on purchasing decisions and location has a positive and significant effect on purchasing decisions. For further research, further researchers can develop this research by examining other factors that can influence purchasing decisions, for example service quality factors. Further researchers can also use other methods in researching purchasing decisions, for example through in-depth interviews with respondents, so that the information obtained can be more varied and get it directly and for Distro Sport it is expected that future Distro Sport owners will be able to maintain or increase sales.
\end{abstract}

Keywords: Price, Promotion, Location and Purchase Decision

\section{Introduction}

Distro (distribution outlet) is a type of clothing store that sells clothing and sports equipment, which are entrusted by the makers of clothing and some are the results of their own production, this company that became famous, from 2002 it provides sports clothing products (jersey, shoes etc.), which is designed in a simple manner but attracts the attention of women and men consumers with an age range of 5-50 years, one of the well-known distributions in Bekasi is Distro Agung Jaya, located on Jln. Kaswari No. 4 Cikarang Baru Bekasi, in every business activity, basically aims to get the maximum profit in order to maintain the company's presence in the midst of competition. Price is a factor that influences purchasing decisions for Distro Sport because price has an important role as a medium of exchange in the market of a product affecting wages, rent, interest, and profit. That is, price affects product costs and factors in business. Prices are a basic measure of an economic system because prices affect the location of factors of production and prices can also be defined as the amount of money needed to obtain some combination of a product and service that accompanies, promotion is lacking either will 
cause a reduction in consumers or even disappear because consumers switch to service distributions that have affordable prices (Kotler and Armstrong 2016: 60). Promotion is an important factor for Distro Sport in business to be able to compete with others, communication techniques that are used or delivered using media such as the press, television, radio, signage, posters and others, whose purpose is to attract consumers' interest in the results a company's production. The main purpose of promotion is to inform, influence, and persuade and remind target customers about marketing and marketing mix (Kotler and Armstrong 2016: 61).

Location is one of the most important factors in a business that aims to persuade consumers to come to sport distros in meeting their needs. One of the keys to a successful location business is the place where the company must have operations based, stating that choosing a good location is an important decision. First, because the place is a long-term commitment of resources that can reduce the flexibility of the business's future, whether the location has been purchased or only rented. Second, location will influence future growth. And finally, the local environment can change at any time, if the location value deteriorates, then the location of the business must be moved or closed so that the selection of strategic locations is an alternative road and the indicator used in this study is Access, for example the location traversed or easily reached by facilities general transparency of visibility, i.e. locations or places that can be seen clearly from normal viewing distance. traffic (traffic), involves two main considerations of the number of people passing by can provide a great opportunity for the occurrence of buying, namely purchasing decisions that often occur spontaneously, without planning, and or without going through special efforts, traffic congestion and congestion can also be a hindrance. large, comfortable and safe parking lots for both two-wheeled and four-wheeled vehicles (Kotler and Armstrong 2016: 62). Research question below:

a) Will the price set by the sports distro give satisfaction to the purchase decision of the glorious sports distro?

b) Will the promotion offered by the sport distribution will have an impact on the purchase decision of the glorious sporting distributions?

c) Will the location determined by the sports distribution give satisfaction to the purchase decision of the glorious sporting distro consumer?

d) What is the price, promotion and location? which is given by the Distro Sport simultaneously provides purchasing decisions for consumers glorious glorious sport distro

\section{Literature Review}

\subsection{Purchasing Decisions}

Purchasing decisions are a topic that is often researched by companies, because purchasing decisions are an area of loyal life of the company, where purchasing decisions are an important element in increasing consumer buying interest in a company or organization. Kotler and Rusdi et al (2016: 35) purchasing decisions reveal that the consumer decision making process is a stepby-step process used by consumers when buying goods or services. The product purchase

decision making process and the specific service selection process consists of the following sequence (Kotler and Armstrong 2016: 176-178).

\subsection{Price}

According to Stanton, William J. 2014. Principles of Marketing. Subtitles by Sadu Sundaru. 
Umar, 2014. Marketing services. Jakarta: Gramedia Tjiptono and Chandra, 2014;) William J. Stanton. 2014. Marketing Principles. Seventh Edition of the First Volume. Jakarta: Erlangga., Which states that prices are often determined to satisfy demand or reflect the premium consumers are willing to pay for a product or service, Price is a company management system that will determine the appropriate base price for a product or service and must determine strategies regarding price discounts, payment of freight costs and various variables concerned. The price of a product set by the company is determined in accordance with the raw materials and product marketing. Appropriate pricing will increase a company's profit. Product indicators: Registered prices, discounts, rebates, payment periods, credit terms. As for the application of this mix in sport distros is the price of sport distro products adjusted according to the official distributor's decision determined by the existing sports distro in Cikarang Bekasi until it reaches the distributors who work together and are appointed to sport distro consumers. Purchases of sports distro products can be done with a cash system (Kotler and Armstrong 2016: 62).

\subsection{Promotion}

Promotion is an important aspect of a company's marketing management, and is often also said to be a "continuing process". This is because promotion can lead to a series of further activities of the company. Basu Swastha (2014: 237) defines promotion is seen as a flow of information or one-way persuasion made to direct a person or organization to actions that create an exchange in marketing there are 4 main variables and interconnected promotional tasks, namely:

a) Get attention: A company that cannot sell its products if the market does not know the goods. Then the company will publish its products on a large scale so that consumers know about the goods.

b) Maintaining interest: If consumers already know the products of a company, then the company must maintain interest in the products produced, for example, provide samples or samples of these products, price discounts, and so on. If consumers already know the products of a company, then the company must maintain interest in the products produced, for example, provide samples or samples of these products, price discounts, and so on.

c) Cause desire (desire): The company offers additional advantages for consumers so that consumers have the desire to buy products from the company

d) Obtain treatment (action): Of the various businesses carried out by the company, finally consumers decide on the product, whether to use the product or not.

\subsection{Location}

Choosing the right business location will determine the success of the business in the future. Strategic location makes it easier for consumers to reach and also guaranteed security. Thus, there is a relationship between strategic location and the attractiveness of consumers to purchase a product (Kotler and Armstrong 2016: 62). Choosing a trading location is an important decision for a business that has to persuade customers to come to the place of business in meeting their needs. Site selection has a strategic function because 2.4 Location Choosing the right business location will determine the success of the business in the future. Strategic location makes it easier for consumers to reach and also guaranteed security. Thus, there is a relationship between strategic location and the attractiveness of consumers to purchase a product (Kotler and 
Armstrong 2016: 62). Choosing a trading location is an important decision for a business that has to persuade customers to come to the place of business in meeting their needs. Site selection has a strategic function because can help determine the achievement of business entity goals. Lamb, Hair, Mc Daniel. (2014). The location is a strategic place where consumers can reach businesses (places to eat, shopping centers, etc.) easily, safely, and have a large parking area. surrounding socioeconomic characteristics, traffic flow, land costs, regional regulations and public transportation. The retailers must also consider where the competitors are and their own shops, the location is the location of the store or retailer in a strategic area so as to maximize Swastha's profit, (2014: 67).

\section{Research Methods}

This research methodology is designed to answer research questions. This study uses a quantitative method, a method that emphasizes aspects of objectively measuring social phenomena (Sugiono, 2014) based on the title under study, namely "The Effect of Price and Promotion and Location on Purchasing Decisions (Case Study on Consumers at Agung Jaya Distro Sport in Cikarang New) "The author wants to know whether there is an influence between price, promotion and location on purchasing decisions. In this study, researchers used 4 variables, then a minimum sample size of 60 people $(4 \times 15)$. Thus, the total 60 sample respondents were considered to have met the requirements.

\section{Results and discussion}

In analyzing the data this research was conducted through the distribution of questionnaires at the Agung Jaya Distro Sport on Jalan Kasuari No. 4 Cikarang Baru Bekasi the formulation of the problem regarding the extent of the influence of prices, promotions, and location on purchasing decisions at the Distro Sport Agung Jaya on Jalan Kasuari No. 4 Cikarang Baru Bekasi.

Table 1. Multiple Linear Regression Assumption Test Results

\begin{tabular}{lccccc}
\hline Model & $\begin{array}{c}\text { Competency } \\
\text { standards }\end{array}$ & \multicolumn{4}{c}{$\begin{array}{c}\text { Competency } \\
\text { standards }\end{array}$} \\
\hline B & B & Std error & Beta & T & Sig \\
\hline 1.(Constant) & .17 .85 & .659 & & 7.512 & $.0,60$ \\
Price & .590 & .218 & .436 & 2.470 & $.0,10$ \\
Promotion & .595 & .220 & .437 & 2.572 & $.0,20$ \\
Location & .600 & .221 & .438 & 2.673 & $.0,30$ \\
\hline \multicolumn{4}{c}{ Source: Data processed in 2019 Source: Data processed in 2019 }
\end{tabular}

\subsection{T test}

\section{a) Effect of Price (X1) on Purchasing Decisions (Y)}


Price variable has a significant level of 0.010 from the results of the $t$ test the price variable states that the significance of the $t$ test is greater than 0.05 and the regression coefficient has a positive value of 0.590 while the calculated $t$ value obtained is 2,470 greater than the $t$ table is 17.85 which means Hol's hypothesis is rejected and Ha 2 is accepted.

\section{b) Effect of Promotion (X2) on Purchasing Decisions (Y)}

Promotion variable has a significant level of 0.020 from the $t$ test results the price variable states that the significance of the $t$ test is greater than 0.05 and the regression coefficient has a positive value of 0.595 while the calculated $t$ value obtained is 2.572 greater than the $t$ table is 17.85 which means $\mathrm{H} 2$ hypothesis is rejected and $\mathrm{Ha} 2$ is accepted

\section{c) Effect of Location (X3) on Purchasing Decisions (Y)}

Price variable has a significant level of 0.010 from the results of the $t$ test the price variable states that the significance of the $t$ test is greater than 0.05 and the regression coefficient has a positive value of 0.600 while the calculated $t$ value obtained is 2.673 greater than the $t$ table is 17.85 which means the Ho3 hypothesis is rejected and Ha3 is accepted.

\subsection{F test}

From the $\mathrm{f}$ test results obtained from the calculated $\mathrm{f}$ value of 60,000 Because $\mathrm{f}$ count $>\mathrm{f}$ table is $6.276>3.24$ then Ho is rejected and H3 is accepted, meaning that Price, Promotion and Location together influence the purchase decision.

\subsection{Determination Coefficient (Adjusted R2)}

The results of the coefficient of determination in this study were obtained that the presentation price $(\mathrm{X} 1)$ of 0.01 was greater than 0.503 , meaning that there was no Determination Coefficient Meanwhile, indicating that the percentage of Promotion (X2), amounting to 0.253 was greater than 0.5 , it also meant that Determination coefficient occurs and known significant value of the Location variable (X3) that is equal to 0.213 greater than 0.05 means that also does not occur the coefficient of determination.

\section{References}

[1] Akbar (2012). with the title "Analysis of the Effect of Brand Image, Price, and Product Quality on Purchasing Decisions of Toshiba Notebooks" Journal of Introduction to Modern Business Volume 3, Number 10 (2014)

[2] Ameliatun Nisfiah (2014). conducted a study entitled "Analysis of the Effect of Price, Promotion and Location Factors on Housing Purchasing Decisions at PT. Eka Griya Lestari Semarang "

[3] Ayu Hapsari Narendra Putri (2013). with the title analysis of the influence of competitive prices, location and sales promotions on purchasing decisions: Volume 3, Number 4 (2016)

[4] Buchari Alma, (2010). Marketing and Marketing Services, Alfabeta, Bandung 312/5000

[5] Basu, Swastha and Irawan. 2013. Modern Marketing Management. Yogyakarta: Liberty

[6] Basu Swastha, 2013, Introduction to Modern Business, Introduction to Corporate Economics 
Modern, Jakarta: Liberty

[7] Basu Swastha, 2013, Modern Marketing Management, Liberty Offset, Yogyakarta

[8] Suhartanto Dwi (2014)., Marketing Research Methods, Bandung

[9] Evelina (2012), with the title "Influence, Price, Location and Promotion of the Purchase Decision of Telkomflexi Perdana Card in the holy city

[10] Fandy Tjiptono. (2012). Marketing Services, Bayumedia, Malang

[11] Ferdinand, A. (2012), "Structural Equation Modeling in Management Applications Research Models Kotler, Armstrong (2012). Marketing principles, Twelfth Edition, Vol. 1 and 2, Jakarta: Erlangga Kotler, Philip, 2010, Marketing Management, Jakarta Millennium Edition, Prehallindo.

[12] Kotler and Keller, 2012. Marketing Management, Issue 12, Volume 1, PT. Indeks, Jakarta

[13] Lamb, Charles W, Joseph F. Hair and Carl McDaniel. 2010. Marketing. Book 1. First Edition. Salemba Empat. Jakarta.

[14] Lupiyoadi, Hamdani. 2010. Marketing Management Services, Second Edition. Jakarta : Salemba Empat Publisher

[15] M. Rizwar Ghazali (2010). researching on "Analysis of the Effect of Location, Promotion and Service Quality on Purchasing Decisions Volume 3, Number 4 (2016)

[16] Philip Kotler 2016, Marketing Management, Volume I and II, Eleventh Edition, PT. Index, Gramedia, Jakarta

[17] Pradana Jaka Purnama (2011). Researching on "Analysis of the Effects of Products, Prices and Locations on Purchasing Decisions Volume 6, Number 4, April 2017 